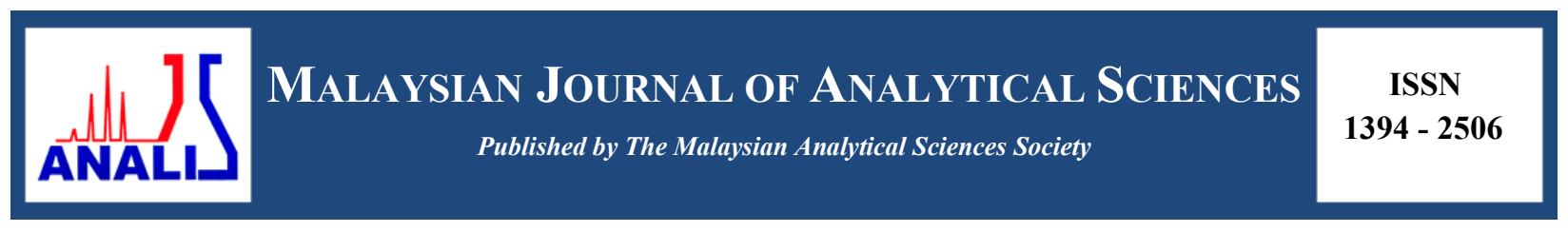

\title{
NEW COMPOUNDS FROM Hydnophytum formicarum YOUNG TUBERS
}

\author{
(Sebatian Baru daripada Bonjolan Muda Hydnophytum formicarum) \\ Nur Shafiqa Abdullah, Wan Yaacob Wan Ahmad*, Noor Aziiraa Sabri \\ School of Chemical Science and Food Technology, Faculty of Science and Technology \\ Universiti Kebangsaan Malaysia, 43600 UKM Bangi, Selangor, Malaysia \\ *Corresponding author: wanyaa@ukm.edu.my
}

Received: 16 January 2017; Accepted: 14 June 2017

\begin{abstract}
The fine powders from young tubers of Hydnophytum formicarum were soaked and extracted by Soxhlet in methanol. Both methanol solutions were evaporated with rotary evaporator to yield cold and hot methanol extracts. Chromatographic separation on the extracts by vacuum liquid and radial chromatography gave two new compounds namely hydnophaldehyde $\left[4,4^{\prime}, 10^{\prime}, 13^{\prime}, 14^{\prime}\right.$-pentamethylgona-7',9'(11')-dien-17'-yl(6)-2,2-dimethylheptanal] (1) and 2-(2'-methoxyphenyl)ethyl palmitate (2). The structures of the above compounds were established by interpreting their spectral data of mass, 1-D Nuclear Magnetic Resonance (NMR), 2-D NMR, and Infrared (IR).
\end{abstract}

Keywords: Rubiaceae, Hydnophytum formicarum, hydnophaldehyde, 2-(2'-methoxyphenyl)ethyl palmitate

\section{Abstrak}

Serbuk halus bonjolan muda Hydnophytum fomicarum direndam dengan metanol dan diekstrak mengunakan kaedah Soxhlet. Kedua-dua larutan metanol disejat dengan penyejat berputar bagi menghasilkan ekstrak metanol sejuk dan panas. Pemisahan kromatografi terhadap ekstrak tersebut dengan kromatografi cecair vakum dan radial memberikan dua sebatian baru bernama hidnofaldehid $\left[4,4^{\prime}, 10^{\prime}, 13^{\prime}, 14^{\prime}\right.$-pentametilgona-7',9'(11')-dien-17'-il(6)-2,2-dimetilheptanal $]$ (1) dan 2-(2'-metoksifenil)etil palmitat (2). Struktur sebatian di atas disahkan dengan mentafsirkan data spektrum bagi jisimnya, Resonans Magnetik Nuklear (RMN) 1-D, RMN 2-D dan Inframerah (IM).

Kata kunci: Rubiaceae, Hydnophytum formicarum, hidnofaldehid, 2-(2'-metoksifenil)etil palmitat

\section{Introduction}

Ant-house plants of Hydnophytum genus are distributed in Southeast Asia, the Pacific region, and also extending into northern Australia state of Queensland. The plants grow on tree branches and on trunks by their epiphytic attaching tubers that look like the swollen succulent stems are having few woody branches with leaves. The genus comprises 55 species, of which 44 are found in New Guinea [1]. Hydnophytum formicarum Jack. (Rubiaceae) forms a symbiotic relationship with ants where its hollow as well as smooth-walled tunnels within the modified stems provide shelter for ant colonies, and in return they provide nutrients to the plants by leaving wastes within the tunnels. In Malaysia, the plant is known as Sarang Semut, Kepala Beruk, and Raja Satong. The tubers of $H$. formicarum have been used in Thai as well as in Malaysian traditional herbal medicine for cancer treatment. To date, only eight known compounds of $\beta$-sitosterol, stigmasterol (steroids), protocatechualdehyde, isoliquiritigenin, butein (phenolic compounds), butein [2,3], sinapinic acid [4] and 7,3',5'-trihydroxyflavanone (flavonoids) [5] were isolated from $H$. formicarum tubers. 
Previous study showed that ethanolic and phenolic-rich extracts of $H$. formicarum tubers possessed both antiproliferative activity as well as HDAC inhibitory activity in HeLa cells that are mediated by induction of apoptosis. On the other hand, methanol, methanol-water (1:1), and water extracts of $H$. formicarum showed selective activity against human tumor cell lines, HeLa, and A549. These results support the efficacy of H. formicarum tubers for the treatment of cervical cancer, colon cancer, and T-cell leukemia in an alternative medicine. Thanaset et al. stated that sinapinic acid that is isolated from H. formicarum tubers, inhibited the growth of HeLa and HT29 cells more effectively than sodium butyrate. However, it inhibited the growth of HCT116 and Jurkat cells less effectively than sodium butyrate. The non-cancer cell line (Vero cells) and breast cancer cell line (MCF-7 cells) appeared to be resistant to both sinapinic acid and sodium butyrate. The growth inhibitory effect of sinapinic acid in HeLa cells was mediated by induction of apoptosis. Hydnophytum formicarum tubers-derived 7,3',5'-trihydroxyflavanone could induce the apoptotic cell death of MCF-7 cells by increasing Bax expression level [6]. In view of the above, we embark on the isolation of new compounds from the extracts of H.formicarum. In this study, methanol was used for maceration and Soxhlet because more polar compounds can be extracted from the young tubers.

\section{Instruments}

\section{Materials and Methods}

The ${ }^{1} \mathrm{H}$ and ${ }^{13} \mathrm{C}$-APT NMR spectra were recorded with Avance III $700 \mathrm{MHz}$ Bruker in $\mathrm{CDCl}_{3}$ with the chemical shifts, $\delta$, in $\mathrm{ppm}$ and the values of coupling constants, $J$, in Hz. LC-MSToF spectra were taken on the Dionex/Bruker Micro ToFQ and FTIR (ATR) spectra were recorded on the Perkin-Elmer Spectrometer 400 FTIR/FT-NIR. Column chromatography (Merck 7747; particle size $0.040-0.063 \mathrm{~mm}$ ), vacuum liquid chromatography (Merck 7747; particle size $0.040-0.063 \mathrm{~mm}$ ), radial chromatography (Merck 7749; particle size $0.040-0.063 \mathrm{~mm}$ ), thin layer chromatography (Merck 5554; mesh $230-400$ ).

\section{Plant materials}

Young tubers of Hydnophytum formicarum were bought in April 2015 from a medicinal plant seller at Kampung Lak Lok, Jertih, Besut, Terengganu. A voucher specimen (UKMB 40312) was deposited at the herbarium of Universiti Kebangsaan Malaysia Bangi (UKMB).

\section{Extraction and isolation}

The air-dried young tubers of Hydnophytum formicarum were cut into small pieces and grounded into fine powder by using mechanical grinding machine. The powders $(1.04 \mathrm{~kg})$ were then extracted with methanol through two types of extraction: maceration in three days, and Soxhlet for a total of 18 hours. The maceration extraction produced 17.0 $\mathrm{g}$ of dark-brown concentrated extract after being evaporated by rotary evaporator. The methanol solution of the extract was extracted by using separatory funnel with $n$-hexane and chloroform to yield extracts of $n$-hexane $(9.0 \mathrm{~g})$, chloroform $(5.0 \mathrm{~g})$, as well as methanol $(3.0 \mathrm{~g})$ [3]. The $n$-hexane extract was subjected to vacuum liquid chromatography (VLC) by using silica gel 7747 (Merck) that eluted with increasing polarity of $n$-hexane and ethyl acetate. The eluents were combined based on their silica gel thin layer chromatography (TLC) 5554 (Merck) profile to give seven fractions (A-G). Fraction B $(1.1 \mathrm{~g})$ was further separated by radial chromatography (RC) by using $n$ hexane-ethyl acetate $(9: 1)$ to yield nine fractions $\left(B_{1}-B_{9}\right)$. The $B_{3}$ fraction was pure to give 2-(2'-methoxyphenyl) ethyl palmitate $(28.0 \mathrm{mg})$.

Meanwhile, the methanol solution of the Soxhlet extraction was evaporated to give $15.0 \mathrm{~g} \mathrm{(1.44 \% )}$ of a dark-brown extract after solvent removal by a rotary evaporator. The extract was subjected to VLC that eluted with increasing polarity of $n$-hexane and ethyl acetate. The eluents were combined based on their TLC profile to give seven fractions (A-G). Fraction C (1.2 g) was further purified by RC using $n$-hexane-ethyl acetate (7:3) to yield eight fractions $\left(\mathrm{C}_{1}-\mathrm{C}_{8}\right)$. The $\mathrm{C}_{2}$ fraction was pure to give hydnophaldehyde $(38.0 \mathrm{mg})$.

\section{Characterization Study}

\section{Results and Discussion}

Hydnophaldehyde (1) $(38.0 \mathrm{mg})$ : white needles; $\mathrm{R}_{\mathrm{f}}=0.94$ ( $n$-hexane-ethyl acetate, 7:3); ESI-MS (m/z): 461.3201 $[\mathrm{M}+\mathrm{Na}]^{+}, \mathrm{C}_{31} \mathrm{H}_{50} \mathrm{O}$; FTIR (ATR) $\mathrm{cm}^{-1}: 2927$ and $2870\left(\mathrm{Csp}^{3}-\mathrm{H}\right), 1698\left(\mathrm{C}=\mathrm{O}\right.$ aldehyde), $1456(\mathrm{C}=\mathrm{C}), 1385\left(\mathrm{Csp} p^{3}-\right.$ $\mathrm{H}), 750\left(\mathrm{Cs} p^{2}-\mathrm{H}\right)$. Data of 1-D and 2-D (HSQC, COSY, HMBC) for ${ }^{1} \mathrm{H}$ and ${ }^{13} \mathrm{C}-\mathrm{APT}$ NMR are in Table 1. 
2-(2'-Methoxyphenyl)ethyl palmitate (2) $(28.0 \mathrm{mg})$ : white powders; $\mathrm{R}_{\mathrm{f}}=0.69$ ( $n$-hexane-ethyl acetate, 9:1); ESIMS (m/z): $413.2417[\mathrm{M}+\mathrm{Na}]^{+}, \mathrm{C}_{25} \mathrm{H}_{42} \mathrm{O}_{3}$; FTIR (ATR) $\mathrm{cm}^{-1}: 2916$ and $2849\left(\mathrm{Csp}^{3}-\mathrm{H}\right), 1711(\mathrm{C}=\mathrm{O}$ ester), 1458 and $1378\left(\mathrm{Csp}^{3}-\mathrm{H}\right), 1268$ and $1158(\mathrm{C}-\mathrm{O}), 1032\left(\mathrm{Csp}^{2}-\mathrm{H}\right), 1516,1473$ and $1463(\mathrm{C}=\mathrm{C}$ aromatic), 718 (ortho subs. benzene). Data of 1-D and 2-D (HSQC, COSY, HMBC) for ${ }^{1} \mathrm{H}$ and ${ }^{13} \mathrm{C}-\mathrm{APT}$ NMR are in Table 2.

Molecular structures of hydnophaldehyde (1) and 2-(2'-methoxyphenyl)ethyl palmitate (2) as shown in Figure 1.

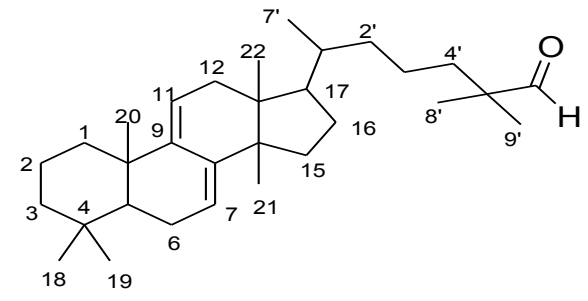

1

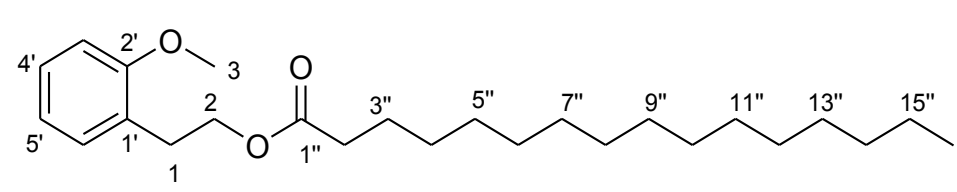

2

Figure 1. Molecular structures of hydnophaldehyde (1) and 2-(2'-methoxyphenyl)ethyl palmitate (2)

Table 1. Spectral data of 1-D and 2-D NMR (700 MHz, $\left.\mathrm{CDCl}_{3}\right)$ of hydnophaldehyde (1)

\begin{tabular}{lcccc}
\hline No. & $\boldsymbol{\delta}_{\mathbf{C}}$ & $\boldsymbol{\delta}_{\mathbf{H}}(\boldsymbol{\Sigma} \mathbf{H}, \boldsymbol{m}, \boldsymbol{J} \mathbf{H z})$ & $\mathbf{C O S Y}$ & $\mathbf{H M B C}$ \\
\hline 1 & 36.9 & - & $\mathrm{H}-2$ & - \\
2 & 19.8 & - & $\mathrm{H}-3$ & - \\
3 & 40.7 & - & - & - \\
4 & 32.8 & - & - & - \\
5 & 47.0 & - & - & $\mathrm{H}-7, \mathrm{H}-11$ \\
6 & 24.3 & $2.40(2 \mathrm{H}, m)$ & $\mathrm{H}-5$ & $\mathrm{H}-7$ \\
7 & 125.8 & $5.29(1 \mathrm{H}, d d, J=7.6,2.4 \mathrm{~Hz})$ & - & - \\
8 & 141.9 & - & - & - \\
9 & 138.4 & - & - & - \\
10 & 39.2 & - & - & $\mathrm{H}-7, \mathrm{H}-11$ \\
11 & 123.3 & $5.35(1 \mathrm{H}, d d, J=9.0,2.4 \mathrm{~Hz})$ & $\mathrm{H}-12$ & - \\
12 & 39.5 & $2.55(2 \mathrm{H}, d, J=2.4 \mathrm{~Hz})$ & - & - \\
13 & 47.6 & - & - & - \\
14 & 50.4 & - & - & - \\
15 & 34.4 & - & - & - \\
16 & 39.6 & - & - & - \\
17 & 52.8 & - & - & $\mathrm{H}-11$ \\
18 & 26.7 & $0.91(3 \mathrm{H}, s)$ & - & - \\
19 & 26.8 & $0.89(3 \mathrm{H}, s)$ & - & - \\
20 & 21.7 & $1.13(3 \mathrm{H}, s)$ & - & - \\
21 & 23.7 & $1.14(3 \mathrm{H}, s)$ & - & - \\
22 & 17.2 & $1.06(3 \mathrm{H}, s)$ & - & - \\
$1^{\prime}$ & 39.0 & & - & - \\
\hline & & - & - & - \\
\hline
\end{tabular}


Nur Shafiqa et al: NEW COMPOUNDS FROM Hydnophytum formicarum YOUNG TUBERS

Table 1 (cont'd). Spectral data of 1-D and 2-D NMR (700 MHz, $\mathrm{CDCl}_{3}$ ) of hydnophaldehyde (1)

\begin{tabular}{lcccc}
\hline No. & $\boldsymbol{\delta}_{\mathbf{C}}$ & $\boldsymbol{\delta}_{\mathbf{H}}(\boldsymbol{\Sigma} \mathbf{H}, \boldsymbol{m}, \boldsymbol{J} \mathbf{H z})$ & $\mathbf{C O S Y}$ & HMBC \\
\hline $2^{\prime}$ & 36.9 & - & - & - \\
$3^{\prime}$ & 23.4 & - & - & - \\
$4^{\prime}$ & 32.7 & - & - & - \\
$5^{\prime}$ & 48.2 & - & - & - \\
$6^{\prime}$ & 207.6 & $9.34(1 \mathrm{H}, s)$ & - & - \\
$7^{\prime}$ & 17.5 & $0.98(3 \mathrm{H}, s)$ & - & - \\
$8^{\prime}$ & 21.3 & $1.14(3 \mathrm{H}, s)$ & - & $\mathrm{H}-6^{\prime}$ \\
$9^{\prime}$ & 21.7 & $1.17(3 \mathrm{H}, s)$ & - & $\mathrm{H}-6^{\prime}$ \\
\hline
\end{tabular}

Table 2. Spectral data of 1-D NMR and 2-D NMR (700 MHz, $\left.\mathrm{CDCl}_{3}\right)$ of 2-(2'-methoxyphenyl) ethyl palmitate (2) and palmitate part of tricosanyl palmitate

\begin{tabular}{|c|c|c|c|c|c|c|}
\hline \multirow[t]{2}{*}{ No. } & \multicolumn{4}{|c|}{ 2-(2'-methoxyphenyl)ethyl palmitate } & \multicolumn{2}{|r|}{ *Palmitate Part } \\
\hline & $\boldsymbol{\delta}_{\mathrm{C}}$ & $\delta_{\mathrm{H}}(\Sigma \mathrm{H}, m, J \mathrm{~Hz})$ & COSY & HMBC & $\boldsymbol{\delta}_{\mathrm{C}}$ & $\delta_{H}(\Sigma H, m, J)$ \\
\hline $1^{\prime}$ & 127.0 & - & - & - & - & - \\
\hline $2^{\prime}$ & 157.0 & - & - & - & - & - \\
\hline $3^{\prime}$ & 109.3 & $7.04(1 \mathrm{H}, s)$ & H-4' & $\mathrm{H}-4^{\prime}$ & - & - \\
\hline $4^{\prime}$ & 144.6 & $7.60(1 \mathrm{H}, d, J=7.5 \mathrm{~Hz})$ & - & $\mathrm{H}-5^{\prime}$ & - & - \\
\hline $5^{\prime}$ & 123.1 & $7.08(1 \mathrm{H}, d, J=8.1 \mathrm{~Hz})$ & H- $6^{\prime}$ & $\mathrm{H}-4^{\prime}$ & - & - \\
\hline $6^{\prime}$ & 129.9 & $7.44(1 \mathrm{H}, d, J=8.3 \mathrm{~Hz})$ & - & $\mathrm{H}-4^{\prime}$ & - & - \\
\hline 1 & 31.9 & $1.58(2 \mathrm{H}, t, J=6.8 \mathrm{~Hz})$ & - & - & - & - \\
\hline 2 & 64.6 & $4.19(2 \mathrm{H}, t, J=6.8 \mathrm{~Hz})$ & $\mathrm{H}-1$ & $\mathrm{H}-1$ & - & - \\
\hline 3 & 56.0 & $3.93(3 \mathrm{H}, s)$ & - & - & - & - \\
\hline $1^{\prime \prime}$ & 167.4 & - & - & - & 171.5 & - \\
\hline $2^{\prime \prime}$ & 31.9 & $1.25(28 \mathrm{H}, b r)$ & - & $\mathrm{H}-2$ & 31.8 & $1.18(28 \mathrm{H}, b r)$ \\
\hline $3^{\prime \prime}$ & 26.0 & & - & - & 29.6 & \\
\hline $4^{\prime \prime}$ & 29.7 & & - & - & 29.6 & \\
\hline $5^{\prime \prime}$ & 29.6 & & - & - & 29.6 & \\
\hline $6^{\prime \prime}$ & 29.6 & & - & - & 29.6 & \\
\hline $7^{\prime \prime}$ & 29.6 & & - & - & 29.6 & \\
\hline $8^{\prime \prime}$ & 29.4 & & - & - & 29.6 & \\
\hline $9^{\prime \prime}$ & 29.4 & & - & - & 29.6 & \\
\hline $10^{\prime \prime}$ & 29.4 & & - & - & 29.4 & \\
\hline $11^{\prime \prime}$ & 28.8 & & - & - & 29.6 & \\
\hline $12^{\prime \prime}$ & 28.4 & & - & - & 29.6 & \\
\hline $13^{\prime \prime}$ & 29.7 & & - & - & 29.6 & \\
\hline $14^{\prime \prime}$ & 26.0 & & - & - & 29.6 & \\
\hline $15^{\prime \prime}$ & 22.7 & & - & - & 22.6 & \\
\hline $16^{\prime \prime}$ & 14.1 & $0.88(3 \mathrm{H}, t, J=6.9 \mathrm{~Hz})$ & - & $\begin{array}{l}\text { H-14", } \\
\text { H-15" }\end{array}$ & 14.3 & $0.81(3 \mathrm{H}, t, J=6.3 \mathrm{~Hz})$ \\
\hline
\end{tabular}

Source: *[7] 
Spectral data of ${ }^{1} \mathrm{H}$ and ${ }^{13} \mathrm{C}$-APT NMR as well as 2-D NMR in Table 1 confirmed that the compound is

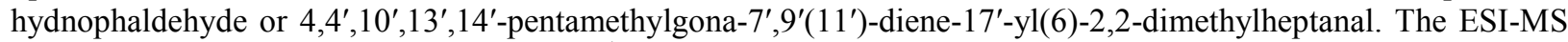
gave molecular ion at $m / z 461.3201[\mathrm{M}+\mathrm{Na}]^{+}$, which corresponded to the molecular formula $\mathrm{C}_{31} \mathrm{H}_{50} \mathrm{O}$. To the best of our knowledge, hydnophaldehyde (steroid) that is isolated from Hydnophytum formicarum is a new compound. Based on Prachayasittikul et al, protocatechualdehyde (phenolic) has been isolated from H. formicarum. The presence of aldehydes among others in the phytochemical screening of H. formicarum ethanol extract supports the existence of hydnophaldehyde in the plant [8]. Figure 2 below shows the correlations between carbon and proton as well as proton and proton from the respective HMBC and COSY spectral data of hydnophaldehyde in Table 1.
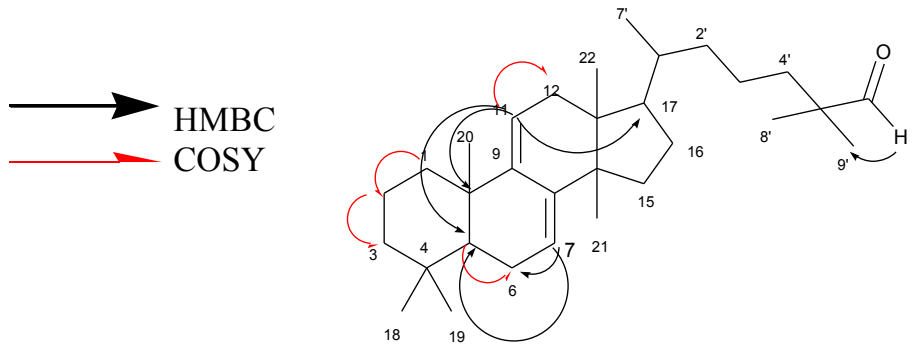

Figure 2. HMBC and COSY correlations of hydnophaldehyde (1)

The NMR spectral data $\left({ }^{1} \mathrm{H}\right.$ and $\left.{ }^{13} \mathrm{C}-\mathrm{APT}\right)$ in Table 2 is in agreement that it is compound that is named as 2-(2'methoxyphenyl) ethyl palmitate. The ESI-MS exhibited molecular ion at $m / z 413.2417[\mathrm{M}+\mathrm{Na}]^{+}$, which is matched with the molecular formula $\mathrm{C}_{25} \mathrm{H}_{42} \mathrm{O}_{3}$. A 107 species in Rubiaceae family that composed fatty acids in leaves proved that 2-(2'-methoxyphenyl) ethyl palmitate as an ester of palmitic acid is present in Hydnophytum formicarum [9]. Figure 3 shows the HMBC and COSY correlations of 2-(2'-methoxyphenyl) ethyl palmitate.
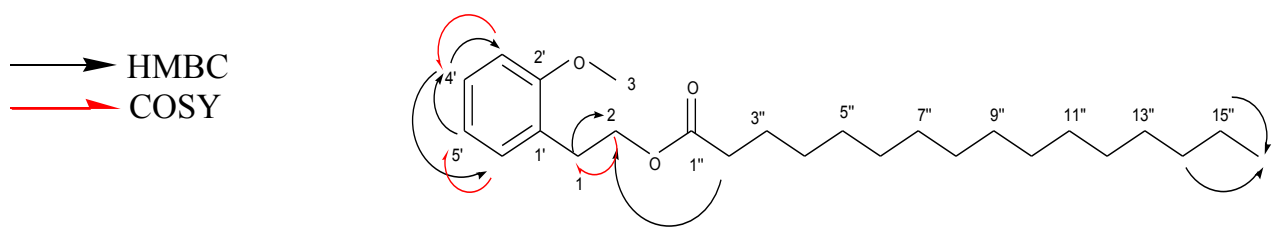

Figure 3. HMBC and COSY correlations of 2-(2'-methoxyphenyl)ethyl palmitate (2)

\section{Conclusion}

Chromatographic separation of two methanol extracts that was derived from maceration and Soxhlet of powder for young tubers of Hydnophytum formicarum yielded two new compounds of hydnophaldehyde $\left(4,4^{\prime}, 10^{\prime}, 13^{\prime}, 14^{\prime}\right.$ pentamethylgona-7',9'(11')-diene-17'-yl(6)-2,2 dimethylheptanal) and 2-(2'-methoxyphenyl)ethyl palmitate. Hydnophaldehyde and 2-(2'-methoxyphenyl) ethyl palmitate can be used to evaluate their biological activities such as for antimicrobial, antioxidants, anti-cancer, and antitumor properties.

\section{Acknowledgement}

We would like to thank the Ministry of Higher Education Malaysia and Universiti Kebangsaan Malaysia (UKM) for the financial support under DLP-2013-018 and LIV-2015-01 grants. Special thanks to School of Chemical Sciences and Food Technology, Faculty of Science and Technology, UKM and Centre for Research and Innovation Management (CRIM), UKM for the technical support on NMR, LC-MSToF and FTIR (ATR) instrumentation.

\section{References}

1. Huxley, C. R. and Jebb, M. H. P. (1991). The tuberous epiphytes of the Rubiaceae 1: A new subtribe - The Hyd nophytinae. Blumea. National Botanic Gardens Glasnevin. Dublin, Ireland. 36: 1 - 20. 
2. Prachayasittikul, S., Buraparuangsang, P., Worachartcheewan, A., Isarankura-Na-Ayudhya, C., Ruchirawat, S. and Prachayasittikul, V. (2008). Antimicrobial and antioxidative activities of bioactive constituents from Hydno phytum formicarum Jack. Molecules (Basel, Switzerland), 13(4): 904 - 921.

3. Prachayasittikul, S., Pingaew, R., Yamkamon, V., Worachartcheewan, A., Wanwimolruk, S., Ruchirawat, S. an d Prachayasittikul, V. (2012). Chemical constituents and antioxidant activity of Hydnophytum formicarum Jack. International Journal of Pharmacology, 8(5): 440 - 444.

4. Thanaset, S., Suwatchai, M., Somprasong, K., Suporn, N., Prasan, S., Chanokbhorn, P., Arpa, S. and Banchob, S. (2013). Histone deacetylase (HDAC) inhibitory and antiproliferative activities of phenolic-rich extracts deriv ed from the rhizome of Hydnophytum formicarum Jack: Sinapinic acid acts as HDAC inhibitor. BMC Complem entary and Alternative Medicine, 13: 232 - 243.

5. Abdullah, H., Pihie, A. H. L. and Hohmann, J. (2009). Release of cytochrome c in MCF-7 cells treated with 7,3' ,5'-trihydroxyflavanone of Hydnophytum formicarum. Biomedical \& Pharmacology Journal, 2(1): 1 - 6.

6. Abdullah, H., Pihie, A.H.L., Hohmann, J. and Molnar, J. (2010). A natural compound from Hydnophytum formi carum induces apoptosis of MCF-7 cells via up-regulation of Bax. Cancer Cell International, (10): 14 - 23.

7. Alam, P., Ali, M. and Aeri, V. (2011). Isolation of four new phytoconstituents from the roots of Albizzia lebbec $k$ Benth. Der Pharmacia Lettre, 3(6): $74-81$.

8. Darwis, D., Hertini, T. and Samito, E. (2014). The effects of Hydnophytum formicarum ethanolic extract towar d lymphocyte, vero and T47d cells proliferation in vitro. Journal of Applied Pharmaceutical Science, 4(6): 103109.

9. Mongrand, S., Badoc, A., Patouille, B., Lacomblez, C., Chavent, M. and Bessoule, J. J (2005). Chemotaxonom $\mathrm{y}$ of the rubiaceae family based on leaf fatty acid composition. Phytochemistry, 66(5): $549-559$. 